\title{
Looking at the soft-bottom around a coastal coral reef: the impact of terrigenous input on Polychaeta (Annelida) community
}

\author{
Michele Quesada-Silva*, Ana Maria Setubal Pires-Vanin
}

Instituto Oceanográfico- Universidade de São Paulo

(Praça do Oceanográfico 191, Cidade Universitária, 05508-120, São Paulo, Brazil)

*Corresponding author: michele.caca@gmail.com

\begin{abstract}
Erosion on coral reefs produces fragments of the constructor organisms that are scattered all around, thus enlarging the reef boundaries. Statistical modelling approach was used to investigate whether the Polychaeta community around Sebastião Gomes reef (Abrolhos Bank, Brazil) is influenced equally by sediment characteristics and/or by position related to the reef, that are variables related to the terrigenous input influence. In July 2007, a period dominated by winds that resuspend fine sediment from the land to coastal reefs, sediment samples were taken on four transects perpendicular to the reef(S, W, N and E) and a total of 121 species of polychaetes were recorded. The most abundant species was the carnivorous Goniadides carolinae and the model selected for it approximates to the best models fitted for both total macrofauna and polychaete abundance. These models represented higher abundance in coarse carbonate sediments on windward reef faces, where there is almost no terrigenous sediment. On the other hand, the Polychaeta richness did not depend on the transects. Sebastião Gomes reef is one of the many coastal reefs from Abrolhos Bank, whose healthy is probably in danger because of the increase of mud related to human activities, as deforestation and, recently, mining waste.
\end{abstract}

Descriptors: Sebastião Gomes, Abrolhos Bank, Macrobenthos, Statistical modelling.

\section{RESUMO}

Fragmentos dos recifes de coral constituem parte do sedimento ao redor dos mesmos, ampliando os limites do recife. Modelos estatísticos foram criados para investigar se a comunidade de poliquetas ao redor do recife Sebastião Gomes (Banco dos Abrolhos, Brasil) é influenciada pelas características do sedimento e/ ou pela posição ao redor do recife, que são variáveis relacionadas à influência do aporte terrígeno. Em julho de 2007, período dominado por ventos que ressuspendem o sedimento fino da costa para os recifes, amostras de sedimento foram coletadas em quatro transectos perpendiculares ao recife $(\mathrm{S}, \mathrm{O}$, $\mathrm{N}$ e L). A espécie de poliqueta mais abundante foi o carnívoro Goniadides carolinae e o modelo selecionado para descrever a distribuição desta espécie foi muito semelhante aos ajustados tanto para a abundância de macrofauna quanto de poliquetas. Estes modelos apresentaram alta abundância em sedimentos carbonáticos grossos na face do recife exposta aos ventos, onde quase não há sedimento terrígeno. Por outro lado, a riqueza de poliquetas não foi influenciada pela posição dos transectos. Sebastião Gomes é um dos muitos recifes costeiros do Banco dos Abrolhos, cuja saúde está prejudicada devido ao aumento de lama relacionada a atividades humanas, como desmatamento e, recentemente, rejeitos da mineração.

Descritores: Sebastião Gomes, Banco dos Abrolhos, Macrofauna bentônica, Modelagem estatística. 


\section{INTRODUCTION}

Corals and coralline algae are the main contributors to reef structure. They are autogenic engineers as they change the conditions of the physical environment (e.g., current speeds and sedimentation rates) by means of their own bodies (JONES et al., 1994). A continuous process both of construction via the calcification of corals and coralline algae, and destruction via physical and biological erosion forms reef structures (BELLWOOD et al., 2003). Erosion produces fragments of the constructor organisms that are scattered around the reefs, thus enlarging their boundaries (BELLWOOD et al., 2003; LEÃO et al., 2006). Although many small invertebrates can inhabit the soft-bottoms around reefs, few research projects have investigated the community ecology of the macrofauna in reef complexes. In fact, the majority of the studies focus only on corals and fishes (SCHLACHER et al., 1998; HUGHES et al., 2002; LEÃO, 2002; BAILEY-BROCK et al., 2007).

Since the 1980s, when ecological studies of the macrofauna of reef complexes started, the main aim has been to investigate the influence of distance from the reef on the community concerned (RIDDLE et al., 1990; SCHLACHER et al., 1998; NETTO et al., 1999a; NETTO et al., 1999b; LANGLOIS et al., 2005; LANGLOIS et al., 2006). However, it is very difficult to compare these studies since they were conducted on different types of reef (coral reefs, rocky reefs or artificial reefs), different reef habitats (pools, lagoons or the sublittoral zone around the reefs) and on different distance scales (from few meters to few kilometers). Small-scale studies are focused more on biological interactions, while larger commonly address the influence of sediment characteristics on macrofauna. Another less studied aspect is the variability of the composition and distribution of the macrofauna due to its position in relation to the reef, in other words, as to whether there are differences in the community patterns on the windward and leeward reef faces (RIDDLE, 1988; NETTO et al., 1999a).

Polychaetes represent one-third of the total number of macrobenthic species found throughout the oceans (AMARAL; ROSSI-WONGTSCHOWSKI, 2004). These invertebrates play important roles in ecosystem functioning: they are prey to fishes and crabs (VIRNSTEIN, 1977), predators of other macrofaunal organisms (COMMITO, 1982) and allogenic engineers (JONES et al., 1994). In this respect, the scavengers are the main organisms responsible for stimulating the biogeochemical processes of nutrient fluxes and organic matter degradation (GARDNER et al., 1979; MARINELLI, 1992; QUINTANA et al., 2011).

The taxonomic classification of the organisms of an ecosystem constitutes the community structure, while the description of species traits is related to the functional community. Although the first has, traditionally, been the most frequently employed, the use of the functional approach is now being increasingly used, mainly when applied to studies of community responses to disturbances (MOUILLOT et al., 2013). Both approaches answer to the environmental influences but coupled studies are useful to better understand the dynamics of ecosystem functioning (DOLÉDEC et al., 2006). In the present study, trophic habit has been considered a proxy to simplify the understanding of the functional groups (functional community), even knowing that the assumption includes other factors such as mobility of organisms for instance, which is related to the process of bioturbation and nutrient cycling (GERINO et al., 2003; NORLING et al., 2007).

The statistical modelling approach was selected to investigate whether the structure and function (trophic habit) of the polychaete community around a coastal reef from the Abrolhos Bank (Brazil) are influenced equally by sediment characteristics and by position in relation to the reef or exclusively by one or other. We have also sought to answer the question as to whether the distribution of total polychaetes corresponds to that of the total macrofauna, in order to verify the viability of the use of Polychaeta as a good indicator of the macrofaunal patterns in reef sediments. The focus on sediment characteristics was chosen because Abrolhos Bank is a unique reef area where sedimentation rates may be higher than the maximum of $10 \mathrm{mg} \mathrm{cm}^{-2}$ day $^{-1}$ (DUTRA et al., 2006; SEGAL; CASTRO, 2011; CASTRO et al., 2012), a limiting rate usually used to consider the reef healthy (ROGERS, 1990).

Studies of the statistical modelling of marine communities are mainly undertaken for fishery resources (REISS et al., 2011; ROBINSON et al., 2011), but spatial and temporal patterns in benthic communities are well suited to statistical modelling too. According to ROBINSON et al. (2011), there are many data on the distribution of invertebrates that, in general, disperse less than fishes do. WILLEMS et al. (2008), for example, tried to model the habitat preference of a Polychaeta species using different statistical modelling approaches and indicated the need of further research into the modelling of the abundance of macrobenthic species. It is essential first to understand the present distribution patterns of 
species through descriptive models so as later to be able to create predictive models, important tools for ecosystem management and conservation.

\section{MATERIAL AND METHODS}

\section{STUDY SITE}

The Abrolhos Bank is situated on the East Brazilian continental shelf and covers three main megahabitats: reefs $\left(\sim 9,000 \mathrm{~km}^{2}\right)$, soft-bottoms $\left(\sim 19,000 \mathrm{~km}^{2}\right)$ and rhodolith beds $\left(\sim 21,000 \mathrm{~km}^{2}\right)$ (MOURA et al., 2013). The climate is characterized by two main seasons, summer and winter. During summer, winds are N/NE and mean water surface temperature is about $27.5^{\circ} \mathrm{C}$, while in the winter, wind direction changes to S/SE due to the Atlantic Polar Front, that resuspends sediment (BITTENCOURT et al., 2000; LEÃO, 2002; DUTRA et al., 2006; SEGAL et al., 2008; CASTRO et al., 2012).

The reefs of the Abrolhos Bank are situated in two arcs: the Coastal Arc (10 to $20 \mathrm{~km}$ from the coast) and the Outer Arc (60 to $70 \mathrm{~km}$ from the coast) (LEÃO, 1996) (Figure 1a). The sediment between the coast and the Coastal Arc is terrigenous (siliciclastic), whilst around the reefs it is carbonate, and a mix of both types occurs between the reef arcs (LEÃO, 2002; SEGAL; CASTRO, 2011; AMADOFILHO et al., 2012). Sedimentation rates are higher during winter and spring, when they may attain more than $10 \mathrm{mg}$ $\mathrm{cm}^{-2}$ day $^{-1}$ in the coastal arc (DUTRA el al., 2006; SEGAL; CASTRO, 2011; CASTRO et al., 2012).

The Sebastião Gomes reef complex is located in the Coastal Arc of the Abrolhos Bank, close to the Caravelas river mouth, and is part of the Ponta da Baleia/Abrolhos Marine Protected Area. This reef was chosen because it lies inside the area with the highest sedimentation rate of the bank (PATCHINEELAM; SMOAK, 1999; CASTRO et al., 2012) and its island-like format facilitates observation of a possible edge effect of the reef on the polychaete community.

\section{SAMPLING}

In July 2007, four transects perpendicular to the Sebastião Gomes reef (S, W, N and E) were drawn, with 6 stations on each of them (Table 1; Figure 1). The stations were placed at increasing distance from the reef, and up to $18 \mathrm{~m}$ depth. Fauna samples were taken in triplicate with a $0.07 \mathrm{~m}^{2}$ van Veen grab. Sediment was washed onboard through a $0.5 \mathrm{~mm}$ mesh size sieve and the material retained was preserved in $70 \%$ ethanol. Fauna samples were sorted in the laboratory, under the stereomicroscope and the polychaetes identified to species level.

At each station, one extra van Veen grab sampled sediment to analyze grain size and percentages of total organic matter (TOM) and carbonates. Grain size, which is a variable related to the interstitial space available to the fauna, was determined using sieving and pipetting techniques (SUGUIO, 1973) and the resulting fractions were classified according to grain size (WENTWORTH, 1922). In this study, only the fine grain size fraction (< $0.063 \mathrm{~mm}$ ) was considered to represent granulometry, because the sum of the fractions is $100 \%$, i.e., fractions are dependent variables. Carbonate content, which may be a variable related to reef origin of sediments, was determined by acid dissolution (GROSS, 1971), and the TOM through loss on ignition at $450^{\circ} \mathrm{C}$ for 4 hours (BYERS et al., 1978).

\section{DATA ANALYSIS}

All data were analyzed with the $\mathrm{R}$ language ( $\mathrm{R}$ DEVELOPMENT CORE TEAM, 2012). The statistical modelling approach based on maximum likelihood was used to examine the influence of sediment and transects (predictor variables) on the macrofauna and Polychaeta community (response variables). The law of likelihood states that there are many models (hypotheses) which may explain the response variable and that each one has some probability of occurring, and, further, that the model with the highest probability is the most plausible (ROYALL, 2007). Model selections were based on the Akaike Information Criterion (AIC), which is a measurement of the distance between the proposed model and the true unknown model. AIC is calculated from the negative loglikelihood and the number of parameters of the model. The proposed model with the smallest AIC is the best model, but models with $\triangle \mathrm{AIC}$ of less than 2 are equally plausible (BURNHAM; ANDERSON, 2002). Models were calculated with the package "MASS" (VENABLES; RIPLEY, 2002) and selected with the package "bbmle" (BOLKER; R DEVELOPMENT CORE TEAM, 2012).

To test the hypothesis related to the influence of reef distance on community, the sedimentary variables were chosen based on the following reasoning: near the reef, sediment should be more carbonate and coarser due to fragments of corals, resulting in more interstitial space for the infauna inhabit (Figure 2); while far from the reef, sediment should be finer and consequently have a high content of TOM, a food resource for macrofauna and whose accumulation is favored by the fine grains 


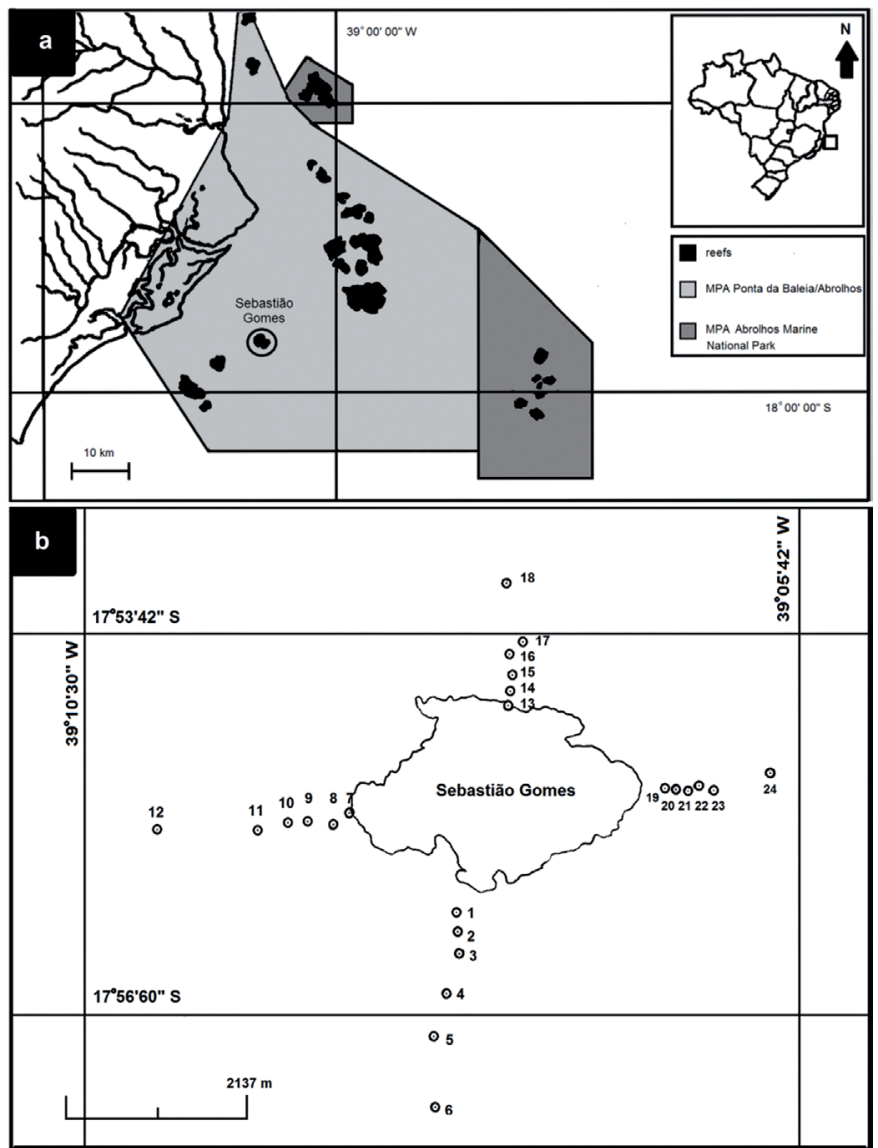

Figure 1. Location of Abrolhos Bank on the East Brazilian continental shelf (a) and sample stations around Sebastião Gomes reef (b).

(SNELGROVE; BUTMAN, 1994). According to the above reasoning, the variables fine grains, carbonates and TOM are correlated. However, we used generalized linear models, one of whose premises is that predictor variables must be independent, in this study. Because of this, score 1 from Principal Component Analysis (PCA) obtained with these variables was used to represent the sediment and was called variable "Sed". PCA was calculated with the package "vegan" (OKSANEN et al., 2012). A model with only the distance between sample stations and the reef as predictor variable was also created to verify whether the distance influences the community in some other way unrelated to sediment.

The generalized linear models created to test whether sediment and/or the position in relation to the reef (on transects $\mathrm{S}, \mathrm{W}, \mathrm{N}$ and $\mathrm{E}$ ) are predictor variables of community distribution patterns were based on negative binomial probability distribution. Some ecologists have realized that count data of aggregate organisms are better fitted to the negative binomial than the Poisson distribution (BOLKER, 2007).

Polychaeta species were classified in one of the following trophic groups in accordance with FAUCHALD and JUMARS (1979): carnivores, herbivores, filterfeeders, deposit-feeders; or in an additional group called omnivores, species which have two or more feeding habits. This same study was used to classify species according to the feeding habit of their families, but other studies were used to revise them (JONES, 1968; NOYES, 1980; WORD, 1980; PLEIJEL, 1983; DOBBS; SCHOLLY, 1986; FONG, 1987; GASTON, 1987; CARRASCO; OYARZÚN, 1988; NIELSEN et al., 1995; FERNER; JUMARS, 1999; GIANGRANDE et al., 2000; BRITAEV; LYSKIN, 2002; LEE et al., 2004; COSTA et al., 2006; PARDO; AMARAL, 2006; DUBOIS et al., 2009; SMART; DASSOW, 2009; PLYUSCHEVA et al., 2010). Generalized linear models with distance, sediment (Sed) and/or transect ( $\mathrm{Tr}$ ) as predictor variables 
Table 1. Distance from the reef, depth and geographic coordinates of sediment samples around Sebastiao Gomes reef complex.

\begin{tabular}{|c|c|c|c|c|c|}
\hline Transect & Station & Distance (m) & Depth (m) & Latitude (S) & Longitude (W) \\
\hline S & 1 & 0 & 10 & $17^{\circ} 55^{\prime} 27^{\prime \prime}$ & $39^{\circ} 08^{\prime} 01^{\prime \prime}$ \\
\hline $\mathrm{S}$ & 2 & 248 & 18 & $17^{\circ} 55^{\prime} 35^{\prime \prime}$ & $39^{\circ} 08^{\prime} 00^{\prime \prime}$ \\
\hline S & 3 & 465 & 18 & $17^{\circ} 55^{\prime} 42^{\prime \prime}$ & $39^{\circ} 07^{\prime} 59^{\prime \prime}$ \\
\hline S & 4 & 960 & 12 & $17^{\circ} 55^{\prime} 58^{\prime \prime}$ & $39^{\circ} 08^{\prime} 05^{\prime \prime}$ \\
\hline S & 5 & 1469 & 17 & $17^{\circ} 56^{\prime} 14^{\prime \prime}$ & $39^{\circ} 08^{\prime} 10^{\prime \prime}$ \\
\hline S & 6 & 2257 & 14 & $17^{\circ} 56^{\prime} 40^{\prime \prime}$ & $39^{\circ} 08^{\prime} 09^{\prime \prime}$ \\
\hline W & 7 & 0 & 7 & $17^{\circ} 54^{\prime} 49^{\prime \prime}$ & $39^{\circ} 08^{\prime} 43^{\prime \prime}$ \\
\hline W & 8 & 257 & 16 & $17^{\circ} 54^{\prime} 54^{\prime \prime}$ & $39^{\circ} 08^{\prime} 50^{\prime \prime}$ \\
\hline W & 9 & 515 & 18 & $17^{\circ} 54^{\prime} 53^{\prime \prime}$ & $39^{\circ} 09^{\prime} 00^{\prime \prime}$ \\
\hline W & 10 & 746 & 18 & $17^{\circ} 54^{\prime} 53^{\prime \prime}$ & $39^{\circ} 09^{\prime} 08^{\prime \prime}$ \\
\hline W & 11 & 1104 & 18 & $17^{\circ} 54^{\prime} 55^{\prime \prime}$ & $39^{\circ} 09^{\prime} 20^{\prime \prime}$ \\
\hline W & 12 & 2274 & 16 & $17^{\circ} 54^{\prime} 55^{\prime \prime}$ & $39^{\circ} 10^{\prime} 00^{\prime \prime}$ \\
\hline $\mathrm{N}$ & 13 & 0 & 3 & $17^{\circ} 54^{\prime} 09^{\prime \prime}$ & $39^{\circ} 07^{\prime} 39^{\prime \prime}$ \\
\hline $\mathrm{N}$ & 14 & 154 & 7 & $17^{\circ} 54^{\prime} 04^{\prime \prime}$ & $39^{\circ} 07^{\prime} 39^{\prime \prime}$ \\
\hline $\mathrm{N}$ & 15 & 370 & 9 & $17^{\circ} 53^{\prime} 57^{\prime \prime}$ & $39^{\circ} 07^{\prime} 38^{\prime \prime}$ \\
\hline $\mathrm{N}$ & 16 & 584 & 8 & $17^{\circ} 53^{\prime} 50^{\prime \prime}$ & $39^{\circ} 07^{\prime} 39^{\prime \prime}$ \\
\hline $\mathrm{N}$ & 17 & 752 & 10 & $17^{\circ} 53^{\prime} 45^{\prime \prime}$ & $39^{\circ} 07^{\prime} 34^{\prime \prime}$ \\
\hline $\mathrm{N}$ & 18 & 1415 & 11 & $17^{\circ} 53^{\prime} 23^{\prime \prime}$ & $39^{\circ} 07^{\prime} 40^{\prime \prime}$ \\
\hline $\mathrm{E}$ & 19 & 0 & 14 & $17^{\circ} 54^{\prime} 40^{\prime \prime}$ & $39^{\circ} 06^{\prime} 37^{\prime \prime}$ \\
\hline $\mathrm{E}$ & 20 & 150 & 16 & $17^{\circ} 54^{\prime} 41^{\prime \prime}$ & $39^{\circ} 06^{\prime} 32^{\prime \prime}$ \\
\hline $\mathrm{E}$ & 21 & 296 & 16 & $17^{\circ} 54^{\prime} 41^{\prime \prime}$ & $39^{\circ} 06^{\prime} 27^{\prime \prime}$ \\
\hline $\mathrm{E}$ & 22 & 413 & 16 & $17^{\circ} 54^{\prime} 39^{\prime \prime}$ & $39^{\circ} 06^{\prime} 23^{\prime \prime}$ \\
\hline $\mathrm{E}$ & 23 & 589 & 16 & $17^{\circ} 54^{\prime} 41^{\prime \prime}$ & $39^{\circ} 06^{\prime} 17^{\prime \prime}$ \\
\hline E & 24 & 1275 & 16 & $17^{\circ} 54^{\prime} 35^{\prime \prime}$ & $39^{\circ} 05^{\prime} 54^{\prime \prime}$ \\
\hline
\end{tabular}

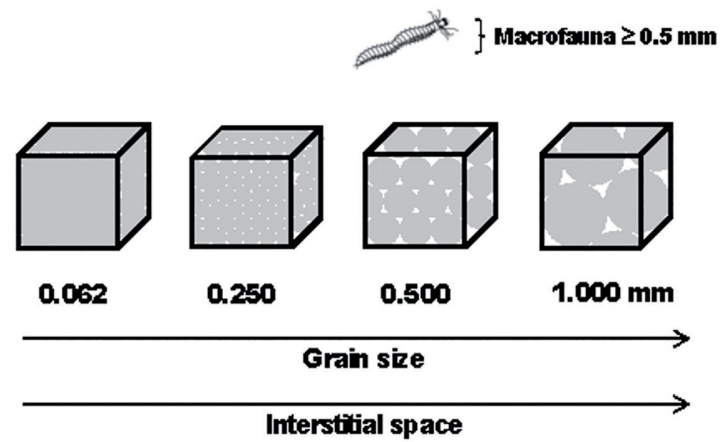

Figure 2. Schematic representation showing how interstitial space for macrofauna inhabits increases with grain size.

were also fitted to evaluate the functional community (trophic groups).

\section{RESULTS}

\section{SOFT-BOTTOM CHARACTERISTICS}

The sediment distribution pattern corresponded to expectations, i.e., near the reef, sediment contained more carbonate and was coarser, except on transect $\mathrm{S}$ (Figure 3). Axis 1 of PCA explained $91.1 \%$ of the total variance of the data and its positive values (hereinafter referred to as the "Sed" variable) represented carbonate sediment stations near the reef while the negative values represented higher percentages of fine grains and TOM (Figure 4).

\section{MACROFAUNA COMMUNITY AND COMMUNITY STRUCTURE OF POLYCHAETA}

In the present study, 11,626 individuals of macrofauna were sampled in the soft-bottom adjacent to Sebastião Gomes reef, comprising 2,432 polychaetes classified in 36 families and 121 species (24, 62, 35 and 91 species were recorded, respectively, in transects $\mathrm{S}, \mathrm{W}, \mathrm{N}$ and E) (Table 2). In the two richest transects (W and E), the richness was higher up to $500 \mathrm{~m}$ from the reef, while in the other two transects ( $\mathrm{S}$ and $\mathrm{N}$ ) it was more uniform along their entire lengh (Figure 5a). Two models tied in trying to explain the richness distribution pattern: Sed and Sed $+\mathrm{Tr}$ 
s

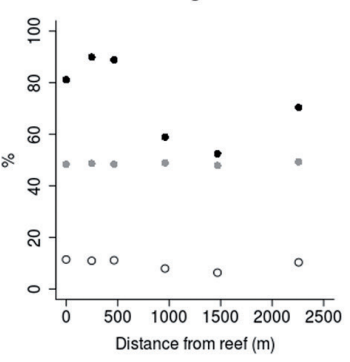

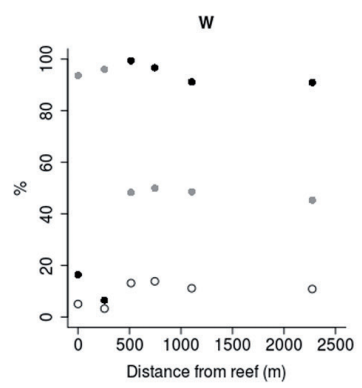
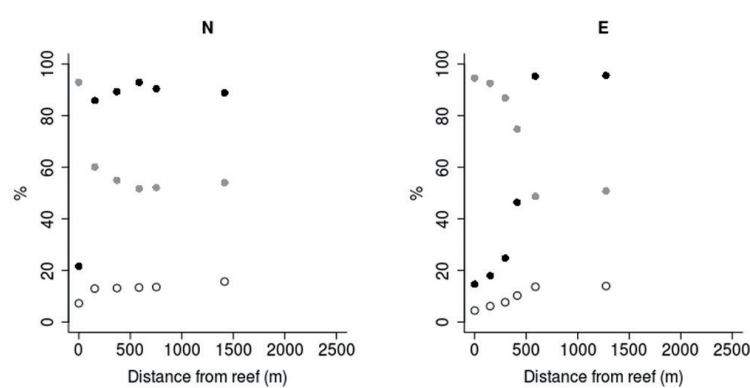

Figure 3. Percentages of fine grains (black), carbonates (gray) and TOM (white) of samples from each transect around Sebastião Gomes reef.

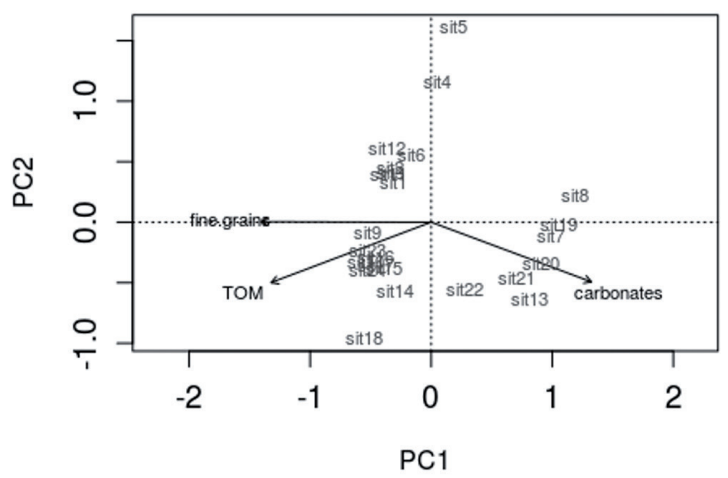

Figure 4. Principal Component Analysis (PCA) of the sedimentary variables of soft bottom around Sebastião Gomes reef.

(Table 3 ). The figure 5 b represents the simplest model, i.e., which considers only sediment as a predictable variable.

Both abundances of macrofauna and polychaetes were higher up to $500 \mathrm{~m}$ from the reef structure, but exactly as with the sediment characteristics, those of transect $\mathrm{S}$ was uniform (Figure 6a,c). The most plausible model to explain the distribution of macrofauna and polychaetes took sediment and transect (position in relation to reef) into consideration (Table 3), higher abundances being associated with coarser carbonate sediment of the $\mathrm{N}$ and $\mathrm{E}$ transects (Figure 6b,d).

With regard to the total abundance of polychaetes, the most abundant species were Goniadides carolinae (813 individuals), Aphelochaeta sp. (170), Leodamas treadwelli (151) and Lumbrineris cf. tetraura (134). These four species accounted for almost $50 \%$ of the total abundance of polychaetes around Sebastião Gomes reef, but only the model selected for $G$. carolinae was similar to that which best fitted the total abundance of this class of the phylum Annelida. The most plausible model to explain the distribution pattern of $G$. carolinae presented an additive effect between sediment and transect, as also did total abundance model, but in this case, transect $\mathrm{N}$ was more favorable to this species and no individual was collected south of the reef (Figure 7a,b). For the third most abundant species, L. treadwelli, sediment with an additive transect effect was again the best model, but the abundance of this species was higher in fine sediment rich in organic matter (Table 3, Figure 7c,d). Aphelochaeta sp. and $L$. cf. tetraura were sampled at almost all stations on all four transects, but only occurred in much greater abundance at station 22, so three models tied (Table 3, Figure 8).

\section{FUNCTIONAL COMMUNITY}

We chose not to calculate models to describe abundance of herbivores and filter-feeders because the former were only represented by $1.5 \%$ of sampled polychaetes and the second by $5.5 \%$. About $50 \%$ of sampled individuals were classified as carnivores and the most abundant species, Goniadides carolinae, represented $81.2 \%$ of this trophic group. Thus, the model selected for carnivore polychaetes was the additive between the variables "Sed" and "Tr", with higher abundance in the coarser sediments on all the transects, mainly to the north of the reef (Figure 9a,b). Deposit-feeders were the second most abundant trophic group (30.3\%) and again the best model fitted took sediment and transect into consideration, though they were more abundant on transect E (Table 3, Figure 9c,d). Finally, abundance of omnivores was higher at one station on each transect, though positioned at different distances, so draws occurred between the models (Table 3, Figure 9e).

\section{DISCUSSION}

\section{TERRIGENOUS AND CARBONATE SEDIMENT AROUND A} COASTAL CORAL REEF INFLUENCED BY POLAR FRONTS

Sample stations located at least $250 \mathrm{~m}$ from the reef showed percentages of carbonates higher than $90 \%$, which means they are true reef sediments (RIDDLE, 1988), with low percentages of fine grains. This kind of sediment is 
Table 2. Checklist of Polychaeta species recorded from sediment around Sebastiao Gomes reef complex.

\begin{tabular}{|c|c|c|}
\hline Family & Species & Stations \\
\hline Ampharetidae & Amphicteis sp. & 22 \\
\hline Amphinomidae & Eurythoe complanata & 10,22 \\
\hline Amphinomidae & Linopherus ambigua & 14,17 \\
\hline Capitellidae & Capitellidae sp.1 & 22 \\
\hline Capitellidae & Capitellidae sp. 2 & 22 \\
\hline Capitellidae & Dasybranchus caducus & 22 \\
\hline Capitellidae & Mediomastus sp. & 22 \\
\hline Capitellidae & Neopseudocapitella brasiliensis & 7 \\
\hline Capitellidae & Notomastus hemipodus & $5,7,11,14,18,21,22$ \\
\hline Capitellidae & Notomastus lobatos & $3,6,10,22,23$ \\
\hline Capitellidae & Scyphoproctus sp.1 & 22 \\
\hline Capitellidae & Scyphoproctus sp.2 & 22 \\
\hline Capitellidae & Scyphoproctus sp.3 & 22 \\
\hline Chrysopetalidae & Bhawania brunnea & 8 \\
\hline Cirratulidae & Aphelochaeta sp. & $1,4,5,6,7,8,11,15,16,18,19,20,21,22$ \\
\hline Cirratulidae & Caulleriella sp.1 & 7,22 \\
\hline Cirratulidae & Caulleriella $\mathrm{sp} .2$ & 19 \\
\hline Cirratulidae & Caulleriella cf. apícula & 19 \\
\hline Cirratulidae & Caulleriella cf. pacifica & 22 \\
\hline Cirratulidae & Chaetozone cf. armata & 8 \\
\hline Cirratulidae & Chaetozone sp.1 & 20,21 \\
\hline Cirratulidae & Chaetozone sp.2 & 22 \\
\hline Cirratulidae & Monticellina sp. & 19 \\
\hline Cossuridae & Cossura sp. & $1,8,14,15$ \\
\hline Dorvilleidae & Meiodorvillea sp. & 19,22 \\
\hline Dorvilleidae & Schistomeringos pectinata & $8,19,22$ \\
\hline Eulepethidae & Grubeulepis fimbriata & $4,5,8,10,14,15,16,23$ \\
\hline Eunicidae & Eunice cf. vittata & $8,20,22$ \\
\hline Eunicidae & Euniphysa sp. & $15,16,17,18$ \\
\hline Eunicidae & Lysidice hebes & $7,8,13,19,22$ \\
\hline Eunicidae & Marphysa sp. & 8,22 \\
\hline Eunicidae & Palola sp. & 8 \\
\hline Fabriciidae & Fabriciola sp. & 22 \\
\hline Fabriciidae & Novafabricia sp. & 22 \\
\hline Fauveliopsidae & Fauveliopsis sp. & $9,10,11,16,22,24$ \\
\hline Flabelligeridae & Pherusa sp. & 8 \\
\hline Goniadidae & Goniadides carolinae & $7,8,13,19,20,21$ \\
\hline Lumbrineridae & Lumbrineriopsis cf. mucronata & 8 \\
\hline Lumbrineridae & Lumbrineris sp. & $1,2,4,5,8,11,20,21,22,23,24$ \\
\hline Lumbrineridae & Lumbrineris cf. tretaura & $2,3,4,5,7,8,9,12,13,14,15,16,17,18,20,22,23,24$ \\
\hline Lumbrineridae & Ninoe brasiliensis & $1,3,4,5,6,10,11,12,14,15,16,17,18,22,23,24$ \\
\hline Magelonidae & Magelona nonatoi & 8 \\
\hline Magelonidae & Magelona papillicornis & $5,7,8,13,14,19,20,22$ \\
\hline Magelonidae & Magelona posterolongata & 5 \\
\hline
\end{tabular}




\begin{tabular}{|c|c|c|}
\hline Maldanidae & Maldanidae sp.1 & 22 \\
\hline Maldanidae & Maldanidae sp.2 & 22 \\
\hline Nephtyidae & Aglaophamus juvenalis & 22 \\
\hline Nephtyidae & Aglaophamus uruguayi & 4,12 \\
\hline Nereididae & Ceratocephale oculata & $5,8,11,20,22$ \\
\hline Nereididae & Neanthes bruaca & $1,2,3,4,5,6,9,11,12,13,14,16,22,24$ \\
\hline Nereididae & Nereididae sp.1 & 8 \\
\hline Nereididae & Nereididae sp.2 & 22 \\
\hline Nereididae & Nereididae sp. 3 & 22 \\
\hline Nereididae & Nereis lanai & 22 \\
\hline Nereididae & Nereis serrata & 8 \\
\hline Nereididae & Nicon sp.1 & 8 \\
\hline Nereididae & Nicon sp.2 & 19 \\
\hline Onuphidae & Diopatra sp.1 & 21 \\
\hline Onuphidae & Diopatra sp.2 & 18 \\
\hline Onuphidae & Diopatra tridentata & 8 \\
\hline Onuphidae & Kinbergonuphis sp.1 & 7 \\
\hline Onuphidae & Kinbergonuphis sp.2 & 7 \\
\hline Onuphidae & Kinbergonuphis cf. fauchaldi & $7,20,22$ \\
\hline Onuphidae & Kinbergonuphis cf. orensanzi & $1,3,7,8,18,20,21,22,23$ \\
\hline Opheliidae & Armandia maculata & 20,22 \\
\hline Opheliidae & Ophelina cylindricaudata & 20,22 \\
\hline Opheliidae & Ophelina sp. & 20 \\
\hline Opheliidae & Polyophthalmus pictus & 7,19 \\
\hline Orbiniidae & Scoloplos agrestis & $5,12,15,16,17,20,21$ \\
\hline Orbiniidae & Scoloplos (Leodamas) rubra & $5,6,15,16,17,18,22,23$ \\
\hline Orbiniidae & Leodamas treadwelli & $1,2,3,4,5,6,7,8,9,10,11,12,14,15,16,17,18,20,23,24$ \\
\hline Oweniidae & Owenia sp. & $7,8,13,19$ \\
\hline Paraonidae & Aricidea $\mathrm{sp}$. & 15,22 \\
\hline Paraonidae & Aricidea (Aricidea) albatrossae & $1,2,4,5,8,15,18,22,24$ \\
\hline Paraonidae & Aricidea (Acmira) catherinae & $4,8,21,22$ \\
\hline Paraonidae & Cirrophorus americanos & 8 \\
\hline Paraonidae & Cirrophorus branchiatus & 19 \\
\hline Paraonidae & Levinsenia cf. gracilis & 19,22 \\
\hline Paraonidae & Paradoneis lyra & $8,19,21,22$ \\
\hline Pectinariidae & Pectinariidae sp.1 & 13 \\
\hline Pectinariidae & Pectinariidae sp.2 & 13 \\
\hline Pholoididae & Pholoe sp. & $19,21,22$ \\
\hline Phyllodocidae & Phyllodoce sp. & 5 \\
\hline Pilargidae & Ancistrosyllis jonesi & $1,3,5,9,11,13,15,16,18,22,23$ \\
\hline Pilargidae & Ancistrosyllis sp. & $7,8,9,10,13,14,19,20$ \\
\hline Pilargidae & Cabira incerta & $1,2,3,4,5,8,9,10,15,17,20,22,24$ \\
\hline Pilargidae & Litocorsa sp. & $9,10,11,16,22,24$ \\
\hline Pilargidae & Sigambra sp. & $2,10,13,17,22,23$ \\
\hline Polynoidae & Eunoe serrata & 8 \\
\hline Polynoidae & Harmothoe cf. aculeata & 18 \\
\hline
\end{tabular}


Polynoidae

Polynoidae

Sabellariidae

Sabellidae

Sabellidae

Sabellidae

Serpullidae

Sigalionidae

Sphaerodoridae

Spionidae

Spionidae

Spionidae

Spionidae

Spionidae

Syllidae

Syllidae

Syllidae

Syllidae

Syllidae

Syllidae

Syllidae

Syllidae

Syllidae

Syllidae

Syllidae

Syllidae

Syllidae

Syllidae

Syllidae

Syllidae

Terebellidae
Malmgreniella cf. macginitiei

Sabellaria sp.

Amphicorina sp.

Amphiglena sp.

Pseudobranchiomma sp.

Salmacina sp.

Fimbriosthenelais marianae

Sphaerodoropsis sp.

Aonides mayaguezensis

Laonice sp.

Microspio sp.

Prionospio sp.

Prionospio heterobranchia

$$
\text { Exogone sp.1 }
$$

Exogone sp.2

Exogone sp.3

Exogone arenosa

Exogone dispar

Exogone simplex

Odontosyllis aracaensis

Perkinsyllis biota

Perkinsyllis augeneri

Sphaerosyllis piriferopsis

Syllis cf. botosaneanui

Syllis cf. cruzi

Syllis garciai

Syllis gracilis

Syllis lutea

Syllis magellanica

Polycirrus cf. tenuiseti
Ysideria sp.

19

18

8

22

8,22

22

22

$4,5,14,16,20$

22

8,19

13,19

22

22

22

$7,8,14,18,19,20,21,22,23$

8,22

19

$7,8,22$

8,22

22

22

19,22

19,22

$7,8,13,14,19,20,21,22$

8,13

8,22

22

8

$8,19,21,22,24$

8

22

b
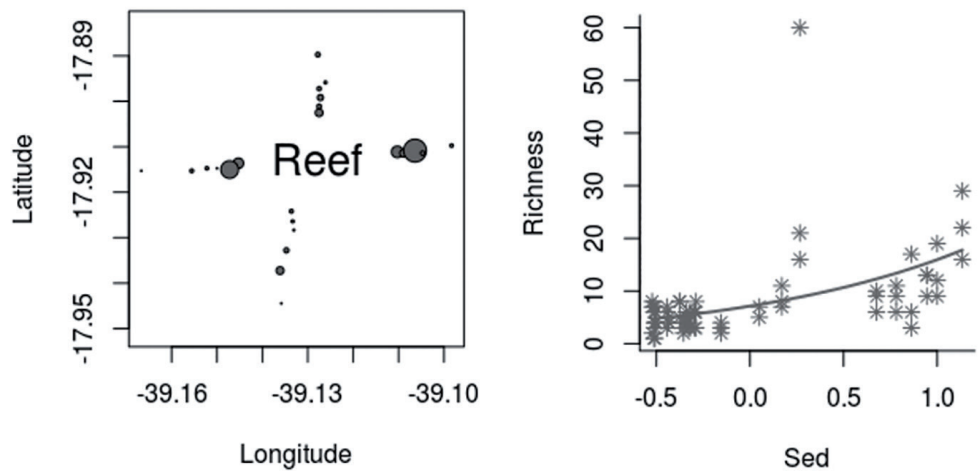

Figure 5. Distribution pattern of Polychaeta richness around Sebastião Gomes reef (circles are proportional to square root of the average of the triplicates) (a) and its selected model (Sed) (b). 
Table 3. Models fitted to describe patterns of total macrofauna, abundance and richness of polychaetes around Sebastião Gomes reef, as well as patterns of the most abundant species (Goniadides carolinae, Aphelochaeta sp., Leodamas treadwelli and Lumbrineris cf. tetraura) and trophic groups of polychaetes (carnivores, deposit-feeders and omnivores). Selected models are in bold. Legend: Par=number of parameters, Dist=distance from reef, Sed=sediment, Tr=transect, $+=$ additive effect, $\mathrm{NA}=$ not available.

\begin{tabular}{|c|c|c|c|c|c|c|c|c|c|c|c|}
\hline \multirow[b]{2}{*}{ Model } & \multirow[b]{2}{*}{ Par } & \multicolumn{2}{|c|}{$\begin{array}{c}\text { Total } \\
\text { Macrofauna }\end{array}$} & \multicolumn{2}{|c|}{ Total polychaetes } & \multicolumn{2}{|c|}{ Carnivores } & \multicolumn{2}{|c|}{ Deposit-feeders } & \multicolumn{2}{|c|}{ Omnivores } \\
\hline & & $\mathrm{AIC}$ & $\Delta \mathrm{AIC}$ & AIC & $\Delta \mathrm{AIC}$ & AIC & $\triangle \mathrm{AIC}$ & AIC & $\Delta \mathrm{AIC}$ & AIC & $\Delta \mathrm{AIC}$ \\
\hline Null & 2 & 859.2 & 119.4 & 648.8 & 76.0 & 510.2 & 78.4 & 472.6 & 33.4 & 376.0 & 33.7 \\
\hline Dist & 3 & 819.1 & 79.3 & 619.1 & 46.2 & 465.7 & 33.9 & 460.5 & 21.3 & 369.1 & 26.8 \\
\hline Sed & 3 & 798.4 & 58.6 & 593.4 & 20.6 & 446.6 & 14.7 & 460.5 & 21.3 & 342.3 & 0.0 \\
\hline $\operatorname{Tr}$ & 5 & 828.9 & 89.0 & 631.7 & 58.8 & 497.6 & 65.8 & 446.9 & 7.7 & 372.7 & 30.5 \\
\hline Dist $+\mathrm{Tr}$ & 6 & NA & NA & 614.9 & 42.1 & 468.7 & 36.9 & 444.4 & 5.2 & 367.4 & 25.2 \\
\hline \multirow[t]{2}{*}{ Sed $+\operatorname{Tr}$} & 6 & 739.9 & 0.0 & 572.9 & 0.0 & 431.8 & 0.0 & 439.2 & 0.0 & 343.1 & 0.8 \\
\hline & & \multicolumn{2}{|c|}{ Polychaeta richness } & \multicolumn{2}{|c|}{ Goniadides carolinae } & \multicolumn{2}{|c|}{ Aphelochaeta sp. } & \multicolumn{2}{|c|}{ Leodamas treadwelli } & \multicolumn{2}{|c|}{ Lumbrineris cf. tetraura } \\
\hline Model & Par & $\mathrm{AIC}$ & $\Delta \mathrm{AIC}$ & AIC & $\Delta \mathrm{AIC}$ & AIC & $\Delta \mathrm{AIC}$ & AIC & $\Delta \mathrm{AIC}$ & AIC & $\Delta \mathrm{AIC}$ \\
\hline Null & 2 & 426.4 & 33.2 & 263.9 & 97.1 & 193.6 & 15.8 & 270.6 & 26.5 & 248.5 & 10.3 \\
\hline Dist & 3 & 415.0 & 21.7 & 1547.1 & 1380.3 & 191.5 & 13.7 & 271.3 & 27.1 & 248.0 & 9.8 \\
\hline Sed & 3 & 394.4 & 1.2 & 1396.6 & 1229.8 & 186.9 & 9.1 & 258.6 & 14.5 & 250.1 & 11.9 \\
\hline $\operatorname{Tr}$ & 5 & 417.5 & 24.2 & 2574.3 & 2407.5 & 177.8 & 0.0 & 251.3 & 8.6 & 238.2 & 0.0 \\
\hline Dist $+\mathrm{Tr}$ & 6 & 410.6 & 17.3 & 906.8 & 740.0 & 179.1 & 1.3 & 253.2 & 9.1 & 238.8 & 0.6 \\
\hline Sed $+\operatorname{Tr}$ & 6 & 393.3 & 0.0 & 166.8 & 0.0 & 178.3 & 0.5 & 244.1 & 0.0 & 238.2 & 0.0 \\
\hline
\end{tabular}

associated with the intense hydrodynamics which occur near reef structures and which can transport fine sediments far from the reef, as stated by WOLANSKI; HAMNER (1988) and NETTO et al. (1999a). However, even the station immediately adjacent to face $\mathrm{S}$ (station 1) was composed predominantly of fine grains. During winter, when this study was undertaken, polar fronts affect the Abrolhos Bank frequently (SEGAL et al., 2008) and they can resuspend the fine grains to the south of the reef and deposit them at the base of reef face S. Nevertheless, during summer, station 1 was composed of thick and carbonate sediment (unpublished data), in agreement with the above postulate.

Percentages of carbonates were calculated for the entire sample sediment and not for each grain fraction, ergo, it is impossible to know if all the fractions contain both terrigenous and carbonate material. However, in view of the hypothesis of resuspension of sediments to the south of the reef, most fine grains are probably of kaolinite clay, which is the main suspended mineral around Sebastião Gomes reef (LEIPE et al., 1999). Clay adsorbs to TOM, favoring its deposition (SNELGROVE; BUTMAN, 1994) and so, higher values of TOM were found at stations with a higher proportion of fine grains. Even the lesser values of TOM (about 5\%) were high when compared to those found in other coastal areas (HSIEH, 1995; SANTOS; PIRES-VANIN, 2004), showing that there is no scarcity of food resources for polychaetes.

Hydrodynamics around shallow reefs can also be generated by winds and determine the sediment deposition around them (WOLANSKI; HAMNER, 1988). Sediments around coastal reefs in the Great Barrier Reef present fewer fine grains and more carbonates to windward than to leeward (RIDDLE, 1988). On the Abrolhos Bank winds are from N/NE for most of the year (DUTRA et al., 2006), so transects $\mathrm{N}$ and $\mathrm{E}$ lie to windward.

\section{WHAT INFLUENCED THE DISTRIBUTION PATTERN} OF COMMUNITY STRUCTURE ON THE SOFT-BOTTOM AROUND THE COASTAL CORAL REEF?

The unique previous study about Polychaeta from sediment around Sebastião Gomes reef was a Rapid Marine Biodiversity Assessment, which consisted in six small samples that recorded only one species of polychaetes: Piromis robertii, family Flabelligeridae (DUTRA et al., 2006). In the present investigation, Syllidae was the Polychaeta family with the largest number of species in Sebastião Gomes reef, followed by Capitellidae, Cirratulidae and Nereididae. In Rocas Atoll (NE Brazil), the most richness families were Nereididae, Sabellidae 
a

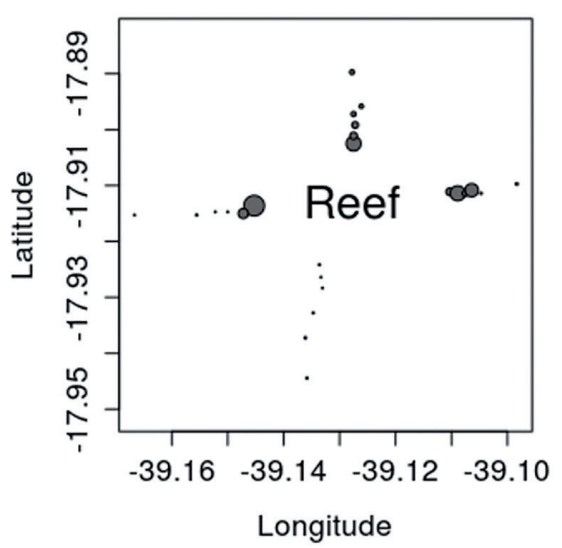

C

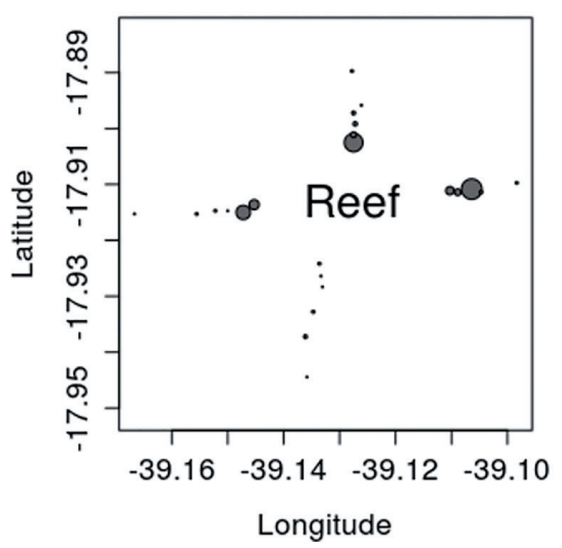

b

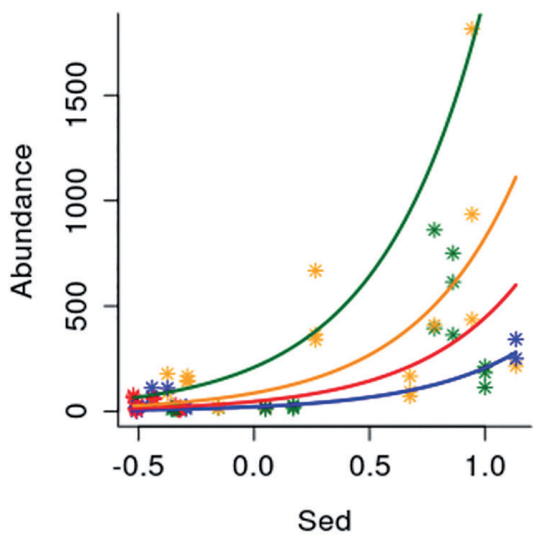

d

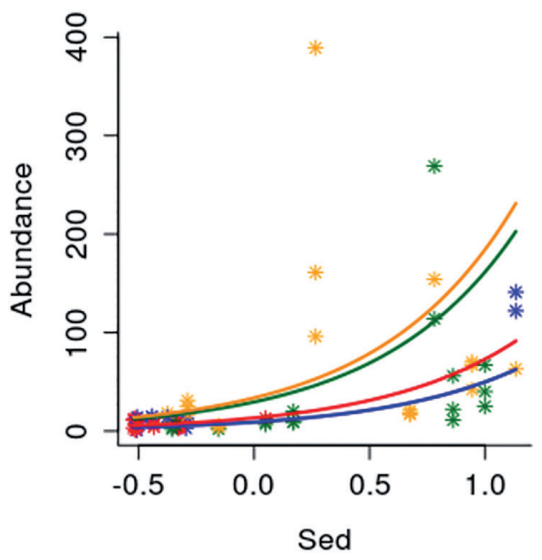

Figure 6. Distribution patterns of macrofauna (a) and polychaete (c) abundance around Sebastião Gomes reef (circles are proportional to square root of the average of the triplicates) and right their selected models $(\mathrm{b}=$ Sed $+\operatorname{Tr}, d=$ Sed $+\operatorname{Tr}$ ). Legend: blue=transect $\mathrm{S}$, red=transect $\mathrm{W}$, green=transect $\mathrm{N}$, orange=transect $\mathrm{E}$.

and Syllidae (PAIVA et al., 2007). Syllidae also was the family with more species in the reefs of Mariana Islands (USA) (BAILEY-BROCK, 2003). Due to the common small size of the species of this family, we recommend that people who work with reef sediment has redoubled attention during the sorting process.

In relation to the distribution pattern, basically, only the coarse carbonate sediment is responsible for the distribution. The two richest transects were $\mathrm{W}$ and $\mathrm{E}$, so the difference of richness between the transects are not related to the winds. NETTO et al. (1999a) also showed no difference between Polychaeta richness from windward and leeward reef faces.

Although the sea-bed in areas denser in total macrofauna and total polychaetes around Sebastião Gomes reef was composed of higher percentages of carbonates and lower percentages of TOM and fine grains, the present results show that the distribution is more related to grain size than to grain composition. Studies carried out with ecosystems without carbonate sediments have shown higher abundance of macrofauna in coarser sediments (GAMBI; BUSSOTTI, 1999), which could be related to an increased availability of interstitial space for macrofauna occupation. However, the carbonate composition of coarse grains underlines the importance of fragments from coral reefs for the establishment of an abundant macrofauna around coral reefs, mainly in coastal areas influenced by fine suspended sediment.

As in the present study, NETTO et al. (1999a) found a higher abundance of total macrofauna and polychaetes on the windward reef face, and supported their results quoting the work of WOLANSKI; HAMNER (1988). According 
a

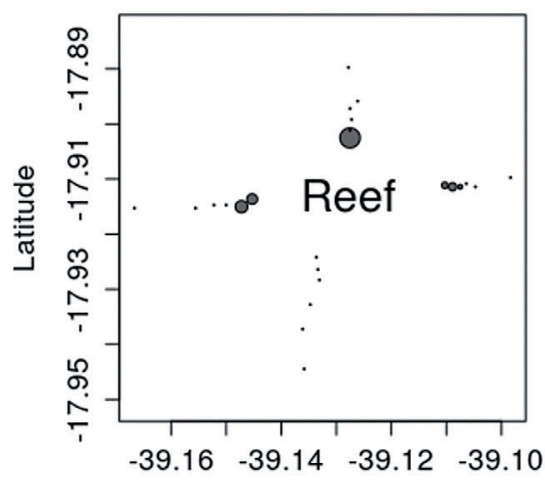

Longitude

C

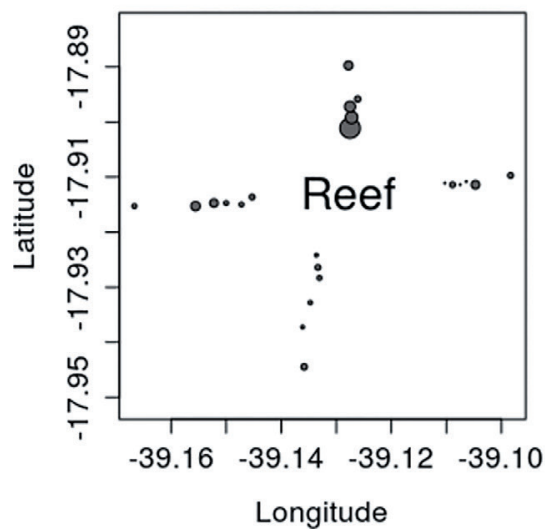

b

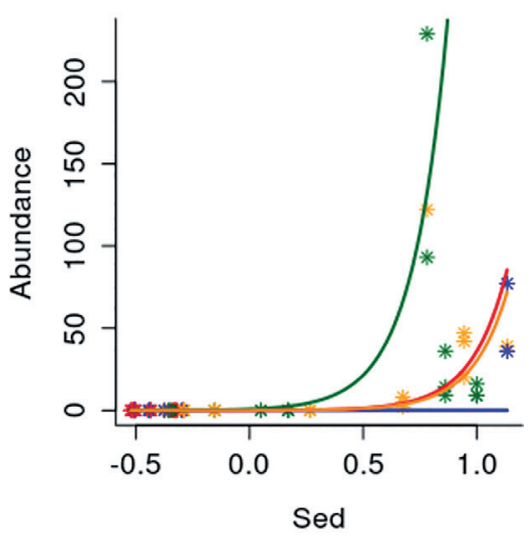

d

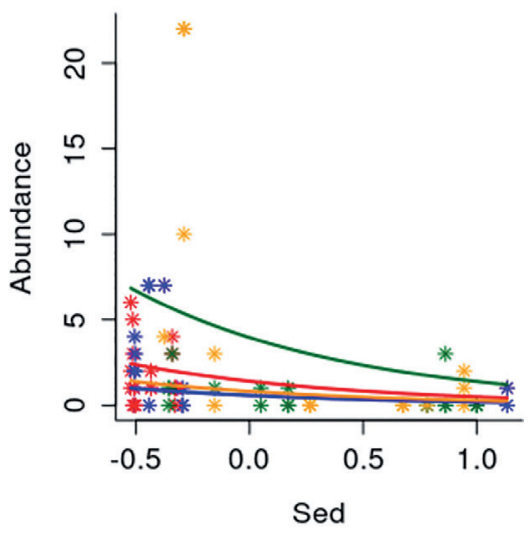

Figure 7. Distribution patterns of Goniadides carolinae (a) and Leodamas treadwelli (c) around Sebastião Gomes reef (circles are proportional to square root of the average of the triplicates) and right their selected models $(b=$ Sed $+\mathrm{Tr}, \mathrm{d}=\mathrm{Sed}+\mathrm{Tr}$ ). Legend: blue=transect $\mathrm{S}$, red=transect $\mathrm{W}$, green=transect $\mathrm{N}$, orange=transect $\mathrm{E}$.

to these latter authors, winds generate topographically controlled currents that aggregate zooplankton near the exposed face of the structure; many benthic species have planktonic larvae, so these currents could prevent the spread of the species.

Regarding more refined models calculated for species, the distribution of the most abundant polychaete Goniadides carolinae was similar to that of the total macrofauna and of the total polychaetes. G. carolinae is a carnivore (FAUCHAULD; JUMARS, 1979), and its greater abundance in coarse sediments was probably related to high abundance of macrofauna prey items at these sites. Leodamas treadwelli was the only case whose selected model indicated an additive effect between sediment and transect with peak abundances found in soft-bottoms with higher values of fine grains and TOM, demonstrating that the general distribution pattern of total polychaetes is not the same for all abundant polychaete species. L. treadwelli has been recorded in both intertidal (RIZZO; AMARAL, 2001) and inner shelf (20 to $50 \mathrm{~m}$ depth) environments in SE Brazil (PAIVA, 1993a), but unlike the present study, the literature does not indicate any grain size preference of the species. This study is the first record of L. treadwelli on the Abrolhos Bank, although other species of the genus Scoloplos (previous genus of $L$. treadwelli) are commonly found in the area (DUTRA et al., 2006).

No distribution pattern was determined for the Cirratulidae Aphelochaeta sp. and despite its being common species in soft-bottoms it is usually dominant in organic rich sediments (ELÍAS; RIVERO, 2009). Few records of Aphelochaeta are reported for Brazil, none for a reef environment (AMARAL et al., 2012). However, it is important to mention that the identification of species of Cirratulidae, mainly Aphelochaeta, is very difficult due to their few taxonomic characters. One of the characteristics of the species of this family is that they succeed in 
a

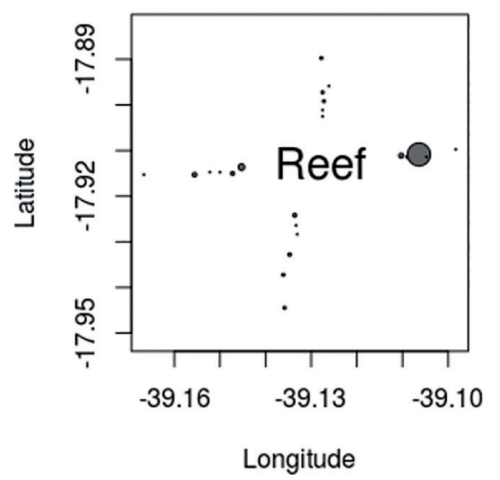

b

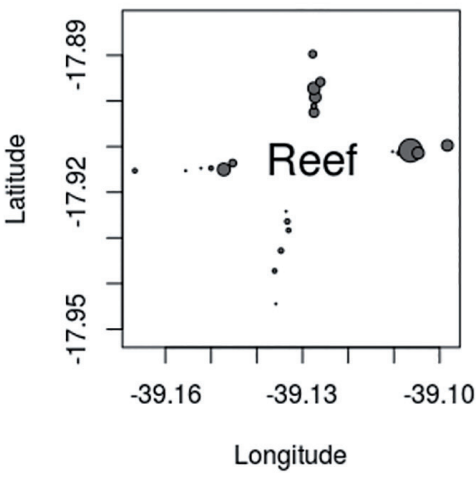

Figure 8. Distribution of Aphelochaeta sp. (a) and Lumbrineris cf. tetraura (b) around Sebastião Gomes reef (circles are proportional to square root of the average of the triplicates).

a

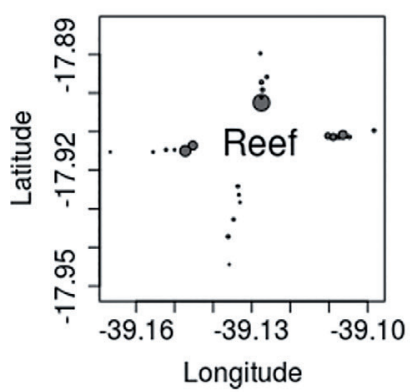

c

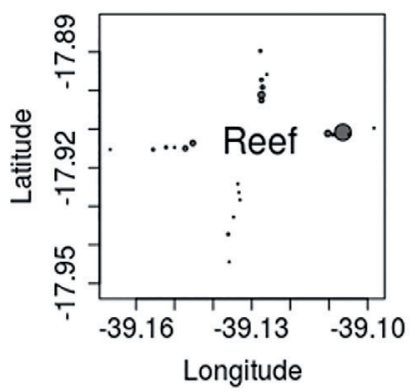

e

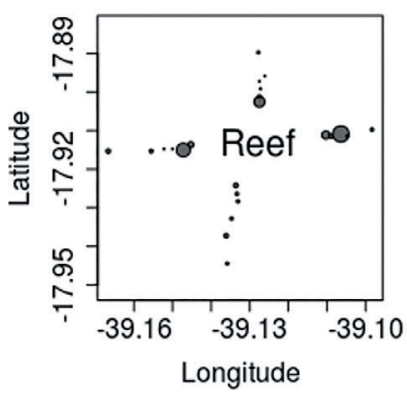

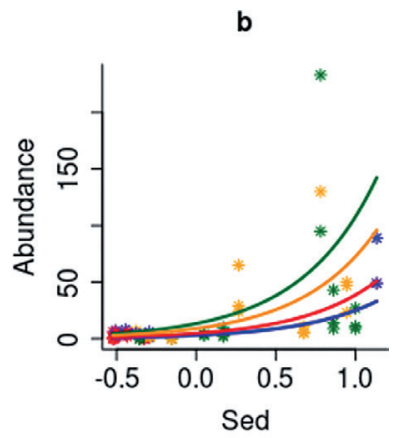

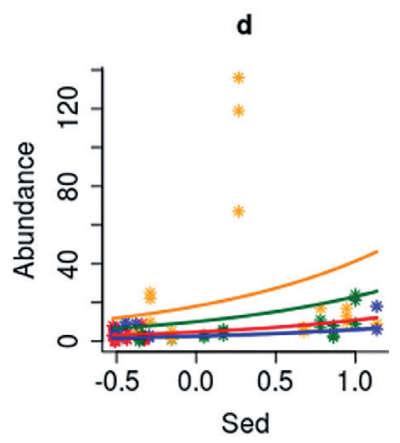

Figure 9. Distribution patterns of carnivorous (a), deposit-feeding (c) and omnivorous polychaetes (e) around Sebastião Gomes reef (circles are proportional to square root of the average of the triplicates) and right their selected models $(b=S e d+T r, d=S e d+T r)$. Legend: blue=transect $S$, red $=$ transect $\mathrm{W}$, green $=$ transect $\mathrm{N}$, orange $=$ transect $\mathrm{E}$. 
occupying any kind of sediment through employing two different techniques. In the first one, they capture food with their palps or directly with the mouth while moving through the sediment (FAUCHALD; JUMARS, 1979; WORD, 1980; PARDO; AMARAL, 2004), which enables them to feed while remaining buried, protecting themselves from physical disturbance and predation. In the second technique, their branchiae may stand out of the sediment (PARDO; AMARAL, 2004), allowing the species to breathe while remaining buried in lowoxygenated sediments.

As well as Aphelochaeta sp., the last species studied Lumbrineris cf. tetraura did not present any distribution pattern in the Sebastião Gomes reef complex. The same result was also found in an investigation conducted in a coral reef complex of Costa Rica (DEAN, 2004). In the present study, the high abundance of $L$. cf. tetraura was found at the station most abundant in total polychaetes, which might be an indication of a high number of prey items available there to this predatory organism (FAUCHALD; JUMARS, 1979; CARRASCO; OYARZÚN, 1988).

In the light of the present results, we can assume that although polychaetes represent only $20 \%$ of total macrofauna, their distribution pattern is representative of that of the global macrofauna, which reinforces the idea that the taxon can be properly taken to represent the general distribution pattern of the macrofaunal organisms of soft-bottoms around coral reefs. Regarding the most abundant species studied, it is interesting to note that only $G$. carolinae followed the same pattern as the total polychaetes and that other abundant species even presented an inverse pattern. It is also important, finally, to highlight that further research into the behavior and feeding habits of these species of polychaetes is essential to understand their distributions.

\section{DID TROPHIC GROUPS RESPOND IN THE SAME WAY AS COMMUNITY STRUCTURE DID?}

The carnivores represented the commonest trophic habit in view of the great abundance of Goniadides carolinae and Lumbrineris cf. tetraura, which resulted in the selection of a model similar to that for G. carolinae but with greater carnivore abundance on transect $E$. Carnivores are common in coarse sediments, where interstitial space is greater and allows the simultaneous presence of both prey and predators (GASTON, 1987; MUNIZ; PIRES, 1999; BARROSO et al., 2002).
The deposit-feeders constituted the second most important group, although they can generally be the most abundant in shallow soft-bottoms (PAIVA, 1993b; COSSON-SARRADIN et al., 1998; MUNIZ; PIRES, 1999; BARROSO et al., 2002). The deposit-feeders more abundant in the present study were: Aphelochaeta sp. (170 individuals), Leodamas treadwelli (151), Aricidea albatrossae (69), Magelona papillicornis (57) and Aricidea catherinae (51). As deposit-feeders live in sediments with high percentages of fine grains and TOM (GASTON, 1987; DEFELICE; PARRISH, 2001), it was expected that their distribution would be similar to the model selected for L. treadwelli. However, this did not occur and our results were similar to those of others who reported a higher abundance of deposit-feeders in coarse sediments (GASTON, 1987; BARROSO et al., 2002), which may be explained by the fact that some depositfeeders can change their habit, feeding on suspended matter when this supply increases, as the species of the family Spionidae (HARTMANN-SCHRÖDER, 1971 apud FAUCHALD; JUMARS, 1979; TAGHON et al., 1980; GASTON, 1987; SNELGROVE; BUTMAN, 1994). On the other hand, deposit-feeder (mainly the surface deposit-feeder) can, further, inhabit coarse sediments due to the input of recent detritus from plankton that sinks to the bottom (GASTON, 1987), and between the five deposit-feeder more dominant, only Leodamas treadwelli belongs to a exclusively subsurface deposit-feeder family (FAUCHALD; JUMARS, 1979).

Carnivores were more abundant on transect $\mathrm{N}$ and deposit-feeders on transect $\mathrm{E}$. This inversion in the abundance of these two trophic groups has also been recorded by PEARSON et al. (1982), who stated that deposit-feeders dominate in sediments with a large quantity of TOM, but carnivores soon appear to feed on them. The presence of carnivores can reduce competition among deposit-feeders by both regulating population size and allowing the coexistence of species of the same trophic habit. Thus perhaps $L$. cf. tetraura is playing this role on transect $\mathrm{E}$.

In the case of herbivores, high abundance was expected near the reef, where seaweeds are more abundant. The presence of exclusively herbivorous polychaetes in soft-bottoms is, however, rare (ABD-ELNABY, 2009) or inexistent (PEARSON et al., 1982; PAIVA, 1993b; COSSON-SARRADIN et al., 1998; MUNIZ; PIRES, 1999; BARROSO et al., 2002; CHEUNG et al., 2008). Even in studies on polychaetes associated with algae, 
herbivore abundance is low (SÁNCHEZ-MOYANO; GARCÍA-ASENCIO, 2009). According to FAUCHALD and JUMARS (1979), the most frequently cited reference, no one family of polychaetes is exclusively herbivorous. Unlike bigger animals, such as fishes, polychaetes are less affected by the chemical defenses of algae (HAY et al., 1988) and, consequently, many polychaetes may feed on seaweed. However, as they can also be carnivores and/ or deposit-feeders, they are, in a general classification, considered omnivores.

Comparative models to explain the abundance of omnivores have not proved efficient, which is to be expected for species that can change their trophic habit in accordance with the available food resource and adapt to different habitats. In the case of filter-feeders, although they can inhabit coarse soft-bottoms to fix their tubes (MUNIZ; PIRES, 1999; BARROSO et al., 2002), their representatives around Sebastião Gomes reef were few. Filter-feeders are more common in hard bottoms (ROUSE; PLEIJEL, 2001), represented by the reef structure itself.

In brief, the models calculated for trophic habits were similar to those for macrofauna and total Polychaeta communities. In other words, high abundances were favored by coarse grains and transects related to windward reef faces. It is highly important to emphasize that distance from the reef exercised no influence on the abundance of the fauna, but reef sediment did. This conclusion arises from the differences found on transect $\mathrm{S}$, the most affected by polar fronts.

\section{THE USEFUL MAXIMUM LIKELIHOOD APPROACH FOR} THE MANAGEMENT AND CONSERVATION OF REEFS

Ecological studies of marine communities through the likelihood approach are used less often than the frequentist approach (e.g., multiple linear regression and $p$-value). Generalized linear models (glm) and model selection based on the Akaike Information Criterion (AIC) used in the present study showed the same patterns of abundance as do classic studies based on multivariate analysis of frequentist statistical methods. So, the tools used here, which do not depend of the Gaussian distribution of the data (premise of the frequentist approach), showed itself to be a useful method to the study of descriptive patterns of macrofauna community and should be used more often, once variables as macrofauna abundance and richness usually do not present Gaussian distribution even after logarithmic transformations. We also highlight and recommend the use of the first score of the Principal
Component Analysis to represent dependent sediment characteristics, mainly fine grains and TOM.

It is very important to understand patterns in the distribution of macrofauna through descriptive models to then create predictive models based on environmental changes, which are important for the management and conservation of reef complexes.

Unfortunately, since November 2015, Brazil is experiencing its worst environmental disaster, which is related to the Samarco mining waste dam collapse in the Doce River. According to the Brazilian Institute of Environment and Renewable Natural Resources (IBAMA) (http://www.ibama.gov.br/publicadas/ documentos-do-ibama-sobre-o-desastre-da-samarcono-rio-doce), a large amount of mud, probably contaminated by metals from Samarco disaster, flowed in direction to Abrolhos Bank and reached the area in July 2016. If this terrigenous sediment deposits around the reefs, the abundance and the diversity of macrofauna community can decrease dramatically, and the coastal reefs will be the first to be affected in the Abrolhos Bank. This work is the most detailed study in Sebastião Gomes reef and we think that these results, previous to the Samarco's disaster, can be used as reference to monitor the area.

These results also can be used in others researches related to environmental disturbances, as climate change and ocean acidification, which indicate that reef complexes may be one of the most impacted marine ecosystems (HOEGH-GULDBERG; BRUNO, 2010). Effects on reef builders, e.g., by carbonate dissolution and the decrease of calcification rate, also could change the quantity and grain size of sediments around coral reefs (ANDERSSON et al., 2007). WIDDICOMBE et al. (2009) have already shown the impact of seawater acidification on macrofauna, mainly that in coarse sediments.

\section{ACKNOWLEDGMENTS}

We wish to thank: all the staff of the Laboratório de Ecologia Bêntica of the Instituto Oceanográfico (Universidade de São Paulo) for their help in sorting the macrofauna samples; Conservation International Brazil (Caravelas City, Bahia State) for their logistic support in the field campaign; PI Prado for his help with the maximum likelihood approach; S Bromberg, M Shimabukuro, MV Fukuda, O Carrerete, and K Paresque for their help with Polychaeta identification. M Quesada-Silva expresses her 
thanks to CAPES for her master's fellowship. This study is part of the interdisciplinary project called "Productivity, sustainability and utilization of the Abrolhos Bank Ecosystem - PROABROLHOS" supported by the Brazilian Research Council - CNPq (420219/2005-6).

\section{REFERENCES}

ABD-ELNABY, F. A. Polychaete study in Northeastern Mediterranean Coast of Egypt. World J. Fish Mar. Sci., v. 1, n. 2, p. 85-93, 2009.

AMADO-FILHO, G. M.; MOURA, R. L.; BASTOS, A. C.; SALGADO, L. T.; SUMIDA, P. Y.; GUTH, A. Z.; FRANCINIFILHO, R. B.; PEREIRA-FILHO, G. H.; ABRANTES, D. P.; BRASILEIRO, P. S.; BAHIA, R. G.; LEAL, R. N.; KAUFMAN, L.; AKLEYPAS, J. A., FRAINA, M.; THOMPSON, F. L. Rhodolith beds are major $\mathrm{CaCO}_{3}$ bio-factories in the tropical South West Atlantic. PLoS ONE, v. 7, n. 4, e35171.

AMARAL, A. C. Z.; NALLIN, S. A. H.; STEINER, T. M.; FORRONI, T. O.; GOMES FILHO, D. Catálogo das espécies de Annelida Polychaeta do Brasil. Campinas: UNICAMP, 2012.

AMARAL, A. C. Z.; ROSSI-WONGTSCHOWSKI, C. L. D. B. Biodiversidade bentônica da Região Sudeste - Sul do Brasil - Plataforma Externa e Talude Superior. São Paulo: Instituto Oceanográfico-USP, 2004.

ANDERSSON, A. J.; BATES, N. R.; MACKENZIE, F. T. Dissolution of Carbonate Sediments Under Rising $p \mathrm{CO}_{2}$ and Ocean Acidification: Observations from Devil's Hole, Bermuda. Aquat. Geochem., v. 13, n. 3, p. 237-264, 2007.

BAILEY-BROCK, J. H. Coral reef polychaetes of Guam and Saipan, Mariana Islands. Micronesica, v. 35-36, p. 200-217, 2003.

BAILEY-BROCK, J.; BROCK, R.; KAM, A.; FUKUNAGA, A.; AKIYAMA, H. Anthropogenic disturbance on shallow cryptofaunal communities in a marine life conservation district on Oahu, Hawaii. Int. Rev. Hydrobiol., v. 92, n. 3, p. 291-300, 2007.

BARroso, R; PAIVA, P. C.; ALVES, O. F. S. Polychaetes trophic structure in Todos os Santos Bay (BA-BRAZIL). Bol. Mus. Nac. Zool., v. 494, p. 1-11, 2002.

BELLWOOD, D. R.; HOEY, A. S.; CHOAT, J. H. Limited functional redundancy in high diversity systems: resilience and ecosystem function on coral reefs. Ecol. Lett., v. 6, n. 4, p. $281-285,2003$.

BITTENCOURT, A. C. S. P.; DOMINGUEZ, J. M. L.; MARTIN, L.; SILVA, I. R. Patterns of sediment dispersion coastwise the State of Bahia - Brazil. An. Acad. Bras. Ciênc., v. 72, n. 2, p. 271-287, 2000.

BOLKER, B. M. Ecological Models and Data in R. Princeton: Princeton University Press, 2007.

BOLKER, B. M.; R DEVELOPMENT CORE TEAM. Package bbmle: Tools for general maximum likelihood estimation. $\mathrm{R}$ package version 1.0.5.2., 2012

BRITAEV, T. A.; LYSKIN, S. A. Feeding of the symbiotic polychaete Gastrolepidia clavigera (Polynoidae) and its interactions with its hosts. Dokl. Biol. Sci., v. 385, p. 352-356, 2002.

BURNHAM, K. P.; ANDERSON, D. R. Model selection and multimodel inference: a practical information-theoretic approach. New York: Springer-Verlag, 2002.

BYERS, S. C.; MILLS, E. L.; STEWART, P. L. A comparison of methods to determining organic carbon in marine sediments, with suggestion for a standard method. Hydrobiologia, v. 58, n. 1, p. 43-47, 1978.

CARRASCO, F. D.; OYARZÚN, C. Diet of the polychaete Lumbrineris tetraura (Schmarda) (Lumbrineridae) in a polluted soft-bottom environment. Bull. Mar. Sci., v. 42, n. 3, p. 358-365, 1988.

CASTRO, C. B.; SEGAL, B.; NEGRÃO, F.; CALDERON, E. N. Four-year monthly sediment deposition on turbid Southwestern Atlantic coral reefs, with a comparison of benthic assemblages. Braz. J. Oceanogr., v. 60, n. 1, p. 49-63, 2012.

CHEUNG, S. G.; LAM, N. W. Y.; WU, R. S. S.; SHIN, P. K. S. Spatio-temporal changes of marine macrobenthic community in sub-tropical waters upon recovery from eutrophication. II. Life-history traits and feeding guilds of polychaete community. Mar. Pollut. Bull., v. 56(2), p. 297-307, 2008.

COMMITO, J. A. Importance of predation by infaunal polychaetes in controlling the structure of a soft-bottom community in Maine, USA. Mar. Biol., v. 68, n. 1, p. 77-81, 1982.

COSSON-SARRADIN, N.; SIBUET, M.; PATERSON, G. L. J.; VANGRIESHEIM, A. Polychaete diversity at tropical Atlantic deep-sea sites: environmental effects. Mar. Ecol. Prog. Ser., v. 165, p. 173-185, 1998.

COSTA, P. F.; OLIVEIRA, R. F.; FONSECA, L. C. Feeding Ecology of Nereis diversicolor (O.F. Müller) (Annelida, Polychaeta) on Estuarine and Lagoon Environments in the Southwest Coast of Portugal. Panam. J. Aquat. Sci., v. 1, n. 2, p. 114-126, 2006.

DEAN, H. K. Marine biodiversity of Costa Rica: Class Polychaeta (Annelida). Rev. Biol. Trop., v. 52, Suppl 2, p. 131-181, 2004.

DEFELICE, R. C.; PARRISH, J. D. Physical processes dominate in shaping invertebrate assemblages in reef-associated sediments of an exposed Hawaiian coast. Mar. Ecol. Prog. Ser., v. 215, p. 121131, 2001.

DOBBS, F. C.; SCHOLLY, T. A. Sediment processing and selective feeding by Pectinaria koreni (Polychaeta: Pectinariidae). Mar. Ecol. Prog. Ser., v. 29, p. 165-176, 1986.

DOLÉDEC, S.; PHILLIPS, N.; SCARSBROOK, M.; RILEY, R. H.; TOWNSEND, C. R. Comparison of structural and functional approaches to determining landuse effects on grassland stream invertebrate communities. J. North Am. Benthol. Soc., v. 25, n. 1, p. 44-60, 2006.

DUBOIS, S.; BARILLÉ, L.; COGNIE, B. Feeding response of the polychaete Sabellaria alveolata (Sabellariidae) to changes in seston concentration. J. Exp. Mar. Biol. Ecol., v. 376, n. 2, p. 94$101,2009$.

DUTRA, G. F. G. R.; ALLEN, G. R.; WERNER, T.; MCKENNA, S. A. A rapid marine biodiversity assessment of the Abrolhos Bank, Bahia, Brazil: The RAP Bulletin of Biological Assessment. Washington: Conservation International, 2006. 160 p.

DUTRA, L. X. C.; KIKUCHI, R. K. P.; LEÃO, Z. M. A. N. Effects of sediment accumulation on reef corals from Abrolhos, Bahia, Brazil. J. Coast. Res., v. 39, n. 2, p. 633-638, 2006.

ELÍAS, R.; RIVERO, M. S. Two new species of Cirratulidae (Annelida: Polychaeta) from Mar del Plata, Argentina (SW Atlantic). Zoosymposia, v. 2, p. 139-148, 2009.

FAUCHALD, K; JUMARS, P. A. The diet of worms: a study of polychaete feeding guilds. Oceanogr. Mar. Biol. Ann. Rev., v. 17, p. 193-284, 1979.

FERNER, M. C.; JUMARS, P. A. Responses of deposit-feeding spionid polychaetes to dissolved chemical cues. J. Exp. Mar. Biol. Ecol., v. 236, n. 1, p. 89-106, 1999. 
FONG, P. P. Particle-size utilization in the introduced polychaete Neanthes succinea in San Francisco Bay. Pac. Sci., v. 41, n. 1-4, p. 37-43, 1987.

GAMBI, M.C.; BUSSOTI, S.Composition, abundance and stratification of soft-bottom macrobenthos from selected areas of the Ross Sea shelf (Antarctica). Polar Biol., v. 21, n. 6, p. 347-354, 1999.

GARDNER, W. S.; LEE, R. F.; TENORE, K. R.; SMITH, L. W. Degradation of selected polycyclic aromatic hydrocarbons in coastal sediments: importance of microbes and polychaete worms. Water Air Soil Poll., v. 11, n. 3, p. 339-347, 1979.

GASTON, G. R. Benthic Polychaeta of the Middle Atlantic Bight: feeding and distribution. Mar. Ecol. Prog. Ser., v. 36, p. 251-262, 1987.

GERINO, M.; STORA, G.; FRANÇOIS-CARCAILLET, F.; GILBERT, F.; POGGIALE, J. C.; MERMILLOD-BLONDIN, F.; DESROSIERS, G.; VERVIER, P. Macro-invertebrate functional groups in freshwater and marine sediments: a common mechanistic classification. Vie et Milieu, v. 53, n. 4, p. 221-231, 2003.

GIANGRANDE, A; LICCIANO, M.; PAGLIARA, P. The diversity of diets in Syllidae (Annelida: Polychaeta). Cah. Biol. Mar., v. 41, n. 1, p. 55-65, 2000.

GROSS, M. G. Carbon determination. In: CARVER, R. E. (Ed.). Procedures in sedimentary petrology. New York: WileyInterscience, 1971. p. 573-596.

HAY, M. E.; RENAUD, P. E.; FENICAL, W. Large mobile versus small sedentary herbivores and their resistance to seaweed chemical defenses. Oecologia, v. 75, n. 2, p. 246-252, 1988.

HOEGH-GULDBERG, O.; BRUNO, J. F. The impact of climate change on the world's marine ecosystems. Science, v. 328, n. 5985, p. 1523-1528, 2010.

HSIEH, H. L. Spatial and temporal patterns of polychaete communities in a subtropical mangrove swamp: influences of sediment and microhabitat. Mar. Ecol. Prog. Ser, v. 127, p. 157-167, 1995.

HUGHES, T. P., BELLWOOD, D. R.; CONNOLLY, S. R. Biodiversity hotspots, centers of endemicity, and the conservation of coral reefs. Ecol. Lett., v. 5, n. 6, p. 775-784, 2002.

JONES, C. G.; LAWTON, J. H.; SHACHAK, M. Organisms as ecosystem engineers. OIKOS, v. 69, n. 3, p. 373-386, 1994.

JONES, M. L. On the morphology, feeding, and behavior of Magelona sp. Biol. Bull., v. 134, n. 2, p. 272-297, 1968.

LANGLOIS, T. J.; ANDERSON, M. J.; BABCOCK, R. C. Inconsistent effects of reefs on different size classes of macrofauna in adjacent sand habitats. J. Exp. Mar. Biol. Ecol., v. 334, n. 2, p. 269-282, 2006.

LANGLOIS, T. J.; ANDERSON, M. J.; BABCOCK, R. C. Reef associated predators influence adjacent soft-sediment communities. Ecology, v. 89, n. 6, p. 1508-1519, 2005.

LEÃO, Z. M. A. N. Abrolhos: O complexo recifal mais extenso do Atlantico Sul. In: SCHOBBENHAUS, C.; CAMPOS, D. A.; QUEIROZ, E. T.; WINGE, M.; BERBERT-BORN, M. L. C. (Eds.). Sitios Geológicos e Paleontológicos do Brasil. $1^{a}$ ed. Brasília: DNPM/CPRM, 2002. p. 345-350.

LEÃO, Z. M. A. N. The coral reefs of Bahia: morphology, distribution and the major environmental impacts. An. Acad. Bras. Ciênc., v. 68, p. 439-452, 1996.

LEÃO, Z. M. A. N.; DUTRA, L. X. C.; SPANÓ, S. The characteristics of bottom sediments. In: DUTRA, G. F.; ALLEN, G. R.; WERNER, T.; MCKENNA, S. A. (Eds.). A rapid marine biodiversity assessment of the Abrolhos Bank, Bahia, Brazil. Washington: Conservation International, 2005. p. 75-81.

LEE, C. G.; HUETTEL, M.; HONG, J. S.; REISE, K. Carrion-feeding on the sediment surface at nocturnal low tides by the polychaete Phyllodoce mucosa. Mar. Biol., v. 145, n. 3, p. 575-583, 2004.
LEIPE, T.; KNOPPERS, B.; MARONE, E.; CAMARGO, R. Suspended matter transport in coral reef waters of the Abrolhos Bank, Brazil. Geo. Mar. Lett., v. 19, n. 3, p. 186-195, 1999.

MARINELLI, R. L. Effects of polychaetes on silicate dynamics and fluxes in sediments: Importance of species, animal activity and polychaete effects on benthic diatoms. J. Mar. Res., v. 50, n. 4, p. 745-779, 1992.

MOUILLOT, D.; GRAHAM, N. A. J.; VILLÉGER, S.; MASON, N. W. H.; BELLWOOD, D. R. A functional approach reveals community responses to disturbances. Trends Ecol. Evol., v. 28, n. 3, p. 167-177, 2013.

MOURA, R. L.; SECCHIN, N. A.; AMADO-FILHO, G. M.; FRANCINI-FILHO, R. B.; FREITAS, M. O.; MINTE-VERA, C. V.; TEIXEIRA, J. B.; THOMPSON, F. L.; DUTRA, G. F.; SUMIDA, P. Y. G.; GUTH, A. Z.; LOPES, R. M.; BASTOS, A. C. Spatial patterns of benthic megahabitats and conservation planning in the Abrolhos Bank. Cont. Shelf. Res., v. 70, p. 109$117,2013$.

MUNIZ, P.; PIRES, A. M. S. Trophic structure of polychaetes in the São Sebastião Channel (southeastern Brazil). Mar. Biol., v. 134, n. 3, p. 517-528, 1999.

NETTO, S. A.; ATTRILL, M. J.; WARWICK, R. N. Sublittoral meiofauna and macrofauna of Rocas Atoll (NE Brazil): indirect evidence of a topographically controlled front. Mar. Ecol. Prog. Ser., v. 179, p. 175-186, 1999a.

NETTO, S. A.; WARWICK, R. N.; ATTRILL, M. J. Meiobenthic and macrobenthic community structure in carbonate sediments of Rocas Atoll (North-east, Brazil). Estuar. Coast. Shelf Sci., v. 48, n. 1, p. 39-50, 1999b.

NIELSEN, A. M.; ERIKSEN, N. T.; IVERSEN, J. J. L.; RIISGÅRD, H. U. Feeding, growth and respiration in the polychaetes Nereis diversicolor (facultative filter-feeder) and $N$. virens (omnivorous) - a comparative study. Mar. Ecol. Prog. Ser., v. 125, p. 149-158, 1995.

NORLING, K.; ROSENBERG, R.; HULTH, S.; GRÉMARE, A.; BONSDORFF, E. Importance of functional diversity and speciesspecific traits of benthic fauna for ecosystem functions in marine sediment. Mar. Ecol. Prog. Ser., v. 332, p. 11-23, 2007.

NOYES, G. S. The biology of Aglaophamus neotenus (Polychaeta: Nephtyidae), a new species from Maine and Canada. Biol. Bull., v. 158, n. 1, p. 103-117, 1980.

OKSANEN, J.; BLANCHET, F. G.; KINDT, R.; LEGENDRE, P.; MINCHIN, P. R.; O'HARA, R. B.; SIMPSON, G. L.; SOLYMOS, P.; STEVENS, M. H. H.; WAGNER, H. Vegan: Community Ecology Package. R package version 2.0-3., 2012.

PAIVA, P. C. Anelídeos poliquetas da plataforma continental norte do Estado de São Paulo: I - Padrões de densidade e diversidade específica. Bol. Inst. Oceanogr., v. 41, n. 1-2, p. 69-80, 1993 a.

PAIVA, P. C. Trophic structure of a shelf polychaete taxocoenosis in southern Brazil. Cah. Biol. Mar., v. 35, p. 39-55, 1993 b.

PAIVA, P. C.; YOUNG, P. S.; ECHEVERRÍA, C. A. The Rocas Atoll, Brazil: a preliminary survey of the crustacean and polychaete fauna. Arq. Mus. Nac. (Rio de J.), v. 65, n. 3, p. 241-250, 2007.

PARDO, E. V.; AMARAL, A. C. Z. Feeding behavior of the cirratulid Cirriformia filigera (Delle Chiaje, 1985) (Annelida: Polychaeta). Braz. J. Biol., v. 64, n. 2, p. 283-288, 2004.

PARDO, E. V.; AMARAL, A. C. Z. Foraging and mobility in thre species of Aciculata (Annelida: Polychaeta). Braz. J. Biol., v. 66, n. 4, p. 1065-1072, 2006.

PATCHINEELAM, S. R.; SMOAK, J. M. Sediment accumulation rates along the inner eastern Brazilian continental shelf. Geo. Mar. Lett., v. 19, n. 3, p. 196-201, 1999. 
PEARSON, T. H.; DUNCAN, G.; NUTTALL, J. The Loch Eil project: Population fluctuations in the macrobenthos. J. Exp. Mar. Biol. Ecol., v. 56, n. 2-3, p. 305-321, 1982.

PLEIJEL, F. On feeding of Pholoe minuta (Fabricus, 1780) (Polychaeta: Sigalioinidae). Sarsia, v. 68, n. 1, p. 21-23, 1983.

PLYUSCHEVA, M.; MARTIN, D.; BRITAYEV, T. Diet analyses of the scale-worms Lepidonotus squamatus and Harmothoe imbricata (Polychaeta, Polynoidae) in the White Sea. Mar. Biol. Res., v. 6, n. 3, p. 271-281, 2010.

QUINTANA, C. O.; HANSEN, T.; DELEFOSSE, M.; BANTA, G.; KRISTENSEN, E. Burrow ventilation and associated porewater irrigation by the polychaete Marenzelleria viridis. J. Exp. Mar. Biol. Ecol., v. 397, n. 2, p. 179-187, 2011.

R DEVELOPMENT CORE TEAM. $R$ : A language and environment for statistical computing. Vienna: R Foundation for Statistical Computing, 2011.

REISS, H.; CUNZE, S.; KÖNIG, K.; NEUMANN, H.; KRÖNCKE, I. Species distribution of marine benthos: a North Sea case study. Mar. Ecol. Prog. Ser., v. 442, p. 71-86, 2011.

RIDDLE, M. J. Patterns in the distribution of macrofaunal communities in coral reef sediments on the central Great Barrier reef. Mar. Ecol. Prog. Ser., v. 47, p. 281-292, 1988.

RIDDLE, M. J.; ALONGI, D. M.; DAYTON, P. K.; HANSEN, J. A.; KLUMPP, D. W. Detrital pathways in a coral reef lagoon: Macrofaunal biomass and estimates of production. Mar. Biol., v. 104, p. 109-118, 1990.

RIZZO, A. E.; AMARAL, A. C. Z. Spatial distribution of annelids in the intertidal zone in São Sebastião Channel, Brazil. Sci. Mar., v. 65, n. 4, p. 323-331, 2001.

ROBINSON, L. M.; ELITH, J.; HOBDAY, A. J.; PEARSON, R. G.; KENDALL, B. E.; POSSINGHAM, H. P.; RICHARDSON, A. J. Pushing the limits in marine species distribution modeling: lessons from the land present challenges and opportunities. Global Ecol. Biogeogr., v. 20, n. 6, p. 789-802, 2011.

ROGERS, C. S. Responses of coral reefs and reef organisms to sedimentation. Mar. Ecol. Prog. Ser, v. 62, p. 185-202, 1990.

ROUSE, G. W.; PLEIJEL, F. Polychaetes. Oxford: Oxford University Press, 2001.

ROYALL, R. M. The likelihood paradigm for statistical evidence. In: TAPER, M. L.; LELE, S. R. (Eds.). The nature of scientific evidence: Statistical, Philosophical, and Empirical Considerations. Chicago: University of Chicago Press, 2007. p. 119-152.

SÁNCHEZ-MOYANO, J. E.; GARCÍA-ASENCIO, I. Distribution and trophic structure of annelid assemblages in a Caulerpa prolifera bed from southern Spain. Mar. Biol. Res., v. 5, n. 2, p. 122-132, 2009.

SANTOS, M. F. L.; PIRES-VANIN, A. M. S. Structure and dynamics of the macrobenthic communities of Ubatuba Bay, southeastern Brazilian Coast. Braz. J. Oceanogr, v. 52, n. 1, p. 59-73, 2004.
SCHLACHER, T. A.; NEWELL, P.; CLAVIER, J.; SCHLACHERHOENLINGER, M. A.; CHEVILLON, C.; BRITTON, J. Softsediment benthic community structure in a coral reef lagoon - the prominence of spatial heterogeneity and 'spot endemism'. Mar. Ecol. Prog. Ser., v. 174, p. 159-174, 1998.

SEGAL, B.; CASTRO, C. B. Coral community structure and sedimentation at different distances from the coast of the Abrolhos Bank, Brazil. Braz. J. Oceanogr., v. 59, n. 2, p. 119-129, 2011.

SEGAL, B.; EVANGELISTA, H.; KAMPEL, M.; GONÇALVES, A. C.; POLITO, P. S.; SANTOS, E. A. Potential impacts of polar fronts on sedimentation processes at Abrolhos coral reef (SouthWest Atlantic Ocean/Brazil). Cont. Shelf Res., v. 28, n. 4-5, p. 533544, 2008.

SMART, T. I.; DASSOW, G. V. Unusual development of the mitraria larva in the polychaete Owenia collaris. Biol. Bull., v. 217, n. 3, p. 253-268, 2009.

SNELGROVE, P. V. R.; BUTMAN, C. A. Animal-sediment relationships revisited: cause versus effect. Oceanogr. Mar. Biol., v. 32, p. 111-177, 1994

SUGUIO, K. Introdução à sedimentologia. São Paulo: EDUSP, 1973. $317 \mathrm{p}$.

TAGHON, G. L.; NOWELL, A. R. M.; JUMARS, P. A. Induction of suspension feeding in spionid polychaetes by high particulate fluxes. Science, v. 210, n. 4469, p. 562-564, 1980.

VENABLES, W. N.; RIPLEY, B. D. Modern applied statistics with S. New York: Springer, 2002.

VIRNSTEIN, R. E. The importance of predation by crabs and fishes on benthic infauna in Cheasepeake Bay. Ecology, v. 58, n. 6, p. 1200-1217, 1977.

WENTWORTH, C. K. A scale of grade and class terms for clastic sediments. J. Geol., v. 30, n. 5, p. 377-392, 1922.

WIDDICOMBE, S.; DASHFIELD, S. L.; MCNEILL, C. L.; NEEDHAM, H. R.; BEESLEY, A.; MCEVOY, A.; ØXNEVAD, S.; CLARKE, K. R.; BERGE, J. A. Effects of $\mathrm{CO}_{2}$ induced seawater acidification on infaunal diversity and sediment nutrient fluxes. Mar. Ecol. Prog. Ser., v. 379, p. 59-75, 2009.

WILLEMS, W.; GOETHALS, P.; DEN EYNDE, D. V.; HOEY, G. V.; LANCKER, V. V.; VERFAILLIE, E.; VINCX, M.; DEGRAER, $\mathrm{S}$. Where is the worm? Predictive modelling of the habitat preferences of the tube-building polychaete Lanice conchilega. Ecol. Modelling, v. 212, n. 1-2, p. 74-79, 2008.

WOLANSKI, E.; HAMNER, W. M. Topographically controlled fronts in the ocean and their biological influence. Science, v. 241, n. 4862, p. 177-181, 1988.

WORD, J. Q. Classification of benthic invertebrates into Infaunal Trophic Index feeding groups. In: BASCOM, W. (Ed.). Southern California Coastal Water Research Project. Biennial Report 1979-1980. Long Beach: Coastal Water Research Project, 1980. p. $103-121$. 